\author{
Лариса Наконечная \\ ГВУЗ «Прикарпатский нацииональныцй университет имени Василия Стефанька» \\ (Украина)
}

\title{
ГРАММЕМНАЯ ТРАНСПОЗИЦИЯ КАК ЯЗЫКОВОЕ ЯВЛЕНИЕ
}

Современная лингвистика сориентирована на комплексное изучение языковых явлений: анализ формально-грамматических, функционально-коммуникативных и лексико-семантических параметров грамматических категорий и грамматических единиц. Этот подход к анализу языковых фактов является концептуальной основой и для исследования транспозиции.

Транспозиция - многогранное языковое явление, которое охватывает лексико-семантический и грамматический уровни и квалифицируется в широком понимании как любое переносное употребление языковой формы, лексической, морфологической или синтаксической (Вихованець 1997: 57; ЛЭС 1990: 519; Ремчукова 1997: 155).

Транспозиция является выразителем динамичности языка. В её основе лежит явление функционально-семантического несоответствия плана выражения и плана содержания.

Эта статья посвящена анализу граммемной транспозиции как одного из проявлений переходности в языке, которую мы рассматриваем на основе грамматической категории времени глагола в украинском языке.

Транспозиция является способом расширения семантических и функциональных возможностей языковых единиц. Благодаря ей форма языковой единицы получает возможность выполнять, кроме прямых, и непрямые функции, а значение обретает иные способы выражения. Таким образом, транспозиция способствует увеличению выразительных возможностей языковой единицы и языка вообще.

Переносное употребление языковых единиц - явление достаточно распространенное, как на семантическом и словообразовательном уровнях, так и на грамматическом.

Граммемная транспозиция является разновидностью грамматической транспозиции. Кроме граммемной, выделяют еще два типа грамматической 
транспозиции: транспозицию частей речи и транспозицию синтаксических единиц (Вихованець 1997: 58).

Транспозиция на уровне частей речи представляет собой переход из одной части речи в иную, как, например, субстантивация, адъективация, вербализация и другие.

Синтаксическая транспозиция, или транспозиция синтаксических конструкций, представлена разными видами преобразований синтаксических единиц, которые «являются отдельным грамматическим типом, но совпадают по своим семантическим компонентам»: Ребенок радуется / Ребенок рад (Гуйванюк 1999: 14-15, 168).

Граммемная транспозиция касается взаимопереходов между компонентами морфологической, синтаксической и словообразовательной категорий (Вихованець 1997: 59).

В лингвистической литературе существует несколько терминов для обозначения этого языкового явления: граммемная, морфологическая, семантическая транспозиция (Вихованець 1997: 57; Ремчукова 2000; Гуйванюк 1999: 298). Мы отдаем предпочтение первому из них, поскольку считаем термин «граммемная транспозиция» наиболее выразительным, точным. Поскольку, независимо от того, на каком уровне происходит замещение - внутрикатегориальном или межкатегориальном, речь идет о явлении взаимоперехода между граммемами.

Различают два основных уровня граммемной транспозиции: внутрикатегориальный и межкатегориальный (Гак 1998: 194). Первый из них (внутрикатегориальный) касается употребления грамматической формы в значении иного члена той же оппозиции (например, на уровне категории числа, рода, времени, наклонения): Попадись йому на перо, докотись до нього хоча б оия історія з соборною таблицею, він ї̈ не промине, иум підніме до небес (О. Гончар) - формы императива употреблены в значении форм условного наклонения: Було, засяє місячя пожар, І він крадеться з-за густого крака... (М. Рильский) - формы будущего и настоящего времени здесь исполняют роль форм прошедшего времени.

Межкатегориальный уровень касается замещения формы одной грамматической категории формой иной грамматической категории: İxaв ото "Москвичем”, а дочка візьми та й скажи...(А. Димаров) - здесь форма императива употреблена вместо формы прошедшего времени.

Н. В. Гуйванюк определяет такие основные условия существования транспозиционных соотношений в современном украинском языке: 1) общность категориального значения; 2) общность семантико-синтаксической позиции; 3 ) совпадение формально-синтаксической позиции в предложении (Гуйванюк 1999: 168).

Используем эти критерии для анализа граммемной транспозиции, в частности транспозиции временных форм глагола, которая репрезенти- 
рована, например, такой конструкцией: Максим же не крився, хоч словами нічого й не казав, прийде в майстерню й сидить, мичить, сопе, зиркає в мій бік (Ю. Мушкетык). Темпоральное значение этой полипредикативной структуры определяют предикаты, представленные формами прошедшего времени несовершенного вида. Именно они указывают на соотношение других предикатов с действиями прошедшего, следовательно, они указывают на функционирование форм презенса и футурума совершенного вида в значении претерита, то есть на явление транспозиции. Исходим из того, что между частью синтаксической конструкции с предикатами в форме прошедшего несовершенного и частью с предикатами в форме настоящего времени и будущего совершенного существуют объяснительные отношения. При сопоставлении транспонированной временной формы и соответствующей формы, употребленной в прямом темпоральном значении (в этом случае - в значении прошедшего времени), не наблюдаем различия ни на одном из уровней. Единство категориального значения обусловлено именно типом транспозиции - внутрикатегориальной транспозицией в рамках одной части речи, поэтому сохранено как значение времени, так и значение действия. Общность семантико-синтаксической и формально-синтаксической позиций определена центральной позицией глагола как предиката в предложении и сохранением как семантико-синтаксической, так и формально-синтаксической модели конструкции.

Одной из главных черт граммемной транспозиции является противоречие между морфологическим значением грамматической формы и значением, приобретенным ею в результате функционирования, - контекстуальным. Считаем, что именно сопоставление этих значений лежит в основе противопоставления и определения прямого и переносного значений грамматической формы, в частности временной.

Прямым значением грамматической формы считаем такое контекстуальное значение, которое реализует парадигматическое значение формы, которое при этом совпадает с реальными условиями контекста: За день перед тим він поголив голову, тож на знімку тепер виглядає зовсім як козацький характерник (Ю. Андрухович). Здесь морфологическое значение форм прошедшего и настоящего времени совпадает со значениями, которые эти формы выражают в конструкции.

Транспонированное значение грамматической формы возникает в контексте, на уровне предложения, когда морфологическое значение формы подвергается смещению под влиянием контекста, когда контекстуальное значение формы не совпадает с тем, которое предвидено языковой системой, как, например, в предложении I синочок мій, тоді ще маленький, Василько, раз по раз серед ночі зривається: “Мамо, щзо то? Нама хата горить?" (А. Димаров). Темпоральную семантику этой конструкции определяет не предикат в форме глагола настоящего времени зривається, а вставная кон- 
струкция тоді ще маленький с временным конкретизатором тод $i$, что обусловливает смещение в семантике предиката, то есть употребление формы не в прямом, а в транспонированном значении (презенс употреблен в значении претерита). Именно контекстуальное временное значение определяет реальную семантику глагольной формы, то есть переход в семантическую сферу смежной по парадигматическому ряду граммемы.

И так, прямое значение временной формы глагола существует при условии совпадения морфологического и контекстуального значений глагольной формы, а транспонированное - при отсутствии этого совпадения.

М. В. Всеволодова для определения прямого и транспонированного значения временной глагольной формы применяет сопоставление морфологического времени глагола и синтаксического времени предложения, что, по нашему мнению, не противоречит, а только дополняет предыдущий, описанный выше, способ. Совпадение морфологического времени глагола и синтаксического времени предложения свидетельствует о прямом употреблении временной глагольной формы. В случае несовпадения морфологического времени глагола и синтаксического времени предложения возникает переносное употребление временной формы, или её транспозиция (Всеволодова, Ким 2001: 57).

Глагольная форма как грамматический центр предложения в определенных случаях лишена возможности определять синтаксическое время предложения.

Это обусловлено наличием в синтаксической структуре семантически более сильных компонентов (лексических и грамматических), которые, определяя синтаксическое время предложения, освобождают формы глагола «от обязанностей быть маркером этих категорий, что и обусловливает возможности их переносного употребления» (Всеволодова, Ким 2001: 55).

Такими семантически более сильными средствами, которые определяют синтаксическое время предложения и под влиянием которых может возникнуть граммемная транспозиция в рамках грамматической категории времени, в украинском языке чаще всего выступают

- временные конкретизаторы (вчора, завтра, минулого року, тодi, якось, колись и др.): А торік іду я лісом та й бачу сліди - ведмідь був тут (С. Пушик); ...nіслязавтра приїздить лікарка Гаврилюк, і йому стало радісно... (Ю. Щербак);

- частицы було, бувало, як: Бувало, оре та й співає, хоч то на тракторі не до співу, але молода була та й співала (С. Пушик); Дотягнувся рукою до бідолахи, шуо наче песик згорнувся калачиком, та як сіпне за піджак (П. Шевчук);

- вводные слова и вставные конструкции: Попросить обтрусити яблуню або грушу, полагодити радіо або вимикач - Олежка робив усілякі прилади для фізичного кабінету в школі - він і не відмовить (Ю. Мушкетык). 
Кроме этих средств, транспозиция временных форм глагола в украинском языке возможна также при наличии в синтаксической конструкции

- соотношения разновременных форм предикатов (в полипредикативных конструкциях). Когда разные временные формы представляют один и тот же темпоральный план, то есть выражают то же временное значение, одна из них является транспонированной. Главенствующим при определении темпорального плана предложения часто является предикат в форме прошедшего времени несовершенного вида: Аж ось у неділю, тижнів через n'ять, якраз після обіду, коли ми сиділи всі коло хати, лузаючи насіння, дивимось (= побачили) - біжить Пірат, зморений, худючий (А. Довженко); Вісім років їй було, а вона по господарству, як господиня, порається (М. Стельмах);

- дополнительной семантики кратности, которая необходимо присутствует при транспозиции форм футурума в план настоящего неактуального: Прийдеш рано до тракторів, зразу ж тебе обступають з усіх боків - того дай, иьього дай, отого дістань (В. Симоненко); Як травичка в саду підніметься, і реп'яхи, і борщзовик попід тином, кличе він сусіду свого, простака сільського, з косою... (В. Дрозд);

- порядка действий «предшествование - следование». При транспозиции предшествующее по времени действие представлено временной формой, которая в первичной функции соответствует действию-следствию, и наоборот, как, например, в предложениях Значить так: до вечора відпочиваємо, а тільки смеркне, я йду в село (А. Димаров); Задощить знову - пропало тоді сіно (О. Донченко).

Граммемная транспозиция как разновидность грамматической транспозиции характеризуется рядом черт, общих и специфических. Общими, то есть такими, которые присущи не только граммемной транспозиции, но и другим типам грамматической транспозиции, являются следующие:

1. Транспозиция грамматической формы происходит только в «чужом» контексте, то есть в том, который не свойственен ее прямому значению. Между контекстом и первичным (категориальным, морфологическим) значением грамматической формы возникает противоречие. Именно контекст обусловливает смещение формы в свою семантическую зону, идентифицирует новое, переносное, значение. Грамматическая форма выполняет не типичную для себя функцию. Так, например, в предложении I таки доnомагали мені по господарству: припнуть теля, нарвуть кабанові щзириці, нагодують курей, качок (Е. Кравченко) синтаксическое время предложения определяет предикат в форме прошедшего несовершенного допомагали, употребленой в прямом значении, тогда как другие предикаты в форме будущего времени исполняют не присущую им темпоральную функцию, 
выражая значение прошедшего и подчиняясь общей временной семантике контекста.

2. Первичное значение грамматической формы сохраняется, хоть и в некоторой мере модифицируется, усложняется, обогащается новыми смыслами, коннотациями, субъективными, эмоционально-экспрессивными оттенками. Так, в конструкции Він хоча й погано бачить, зате чує, мов сова: вуж повзтиме десь неподалік- почує і скаже: "Отам вуж не спить” (Г. Тютюннык) транспонированные формы будущего несовершенного синкретичны: они полной мерой выражают свое собственное значение и одновременно исполняют роль форм настоящего времени.

3. Прямое и транспонированное значения грамматической формы разнятся денотативной отнесенностью, тогда как транспонированная форма и парадигматический противочлен, функцию которого она исполняет, называют тот же факт внезыковой действительности, то есть являются синонимичными. Соглашаемся с мнением М. В. Всеволодовой о том, что «в случае транспозиции почти всегда возможна замена на форму, выражающую прямое значение» (Всеволодова, Ким 2001: 58).

Сравним темпоральную семантику конструкции с транспонированными временными формами и соответствующими по семантике формами, которые употреблены в прямом значении: Раніше тут, було, тільки й чуєш: стук та стук, - удосвіта, в обід, вечорами при місяиі-Хвиль діжки робить (Г. Тютюннык) / Раніше тут, було, тільки й чув: стук та стук, -удосвіта, в обід, вечорами при місяці - Хвиль діжки робив. Обе конструкции представляют тот же временной план - план прошедшего.

4. Транспозиция интенциональна, она демонстрирует позицию говорящего. Так, например, в предложении Знаєи, зробим так: я йду, вечеряю, а потім сходимось у певному місиі (У. Самчук) транспонированные формы настоящего в значении будущего выражают уверенность говорящего в результативности будущих действий, категоричность высказывания.

Специфичным для граммемной транспозиции является то, что, во-первых, транспозиции подвергаются граммемы одной грамматической категории или разных грамматических категорий одной части речи, во-вторых, замена происходит только в сфере семантики, тогда как морфологическая форма исходной единицы, как и ее синтаксическая функция, сохраняются.

Несмотря на достаточное количество исследований граммемной транспозиции вопросы анализа этого языкового явления не исчерпанны. Считаем важным и необходимым исследование транспозиционных процессов, которые происходят в рамках всех грамматических категорий. 


\section{Библиография}

Вихованець І. Р. (1997), Різновиди транспозииії, [в:] Актуальні проблеми граматики, випуск 2, Кіровоград, с. 57-60.

Всеволодова М. В., Ким Тэ Чжин (2001), Принщипь анализа употребления форм глагольного времени. Прямое и переносное употребление форм настоящего времени глагола в русском языке (в зеркале корейского языка), «Вестник Московского университета», серия 9, Филология, №3, с. 53-78.

Гак В. Г. (1998), Языковые преобразования, Москва: Школа «Языки русской культуры».

Гуйванюк Н. В. (1999), Формально-семантичні співвідношення в системі синтаксичних одиниць, Чернівці: Рута.

Лингвистический эничиклопедический словарь (1990), гл. ред. В. Н. Ярцева. (ЛЭС)

Ремчукова Е. Н. (2000), Морфологическая транспозиция как тип функиионального варьирования грамматической формы, [в:] Проблемы функциональной грамматики. Категории морфологии и синтаксиса в высказывании, Санкт-Петербург, с. 79-90.

Ремчукова Е. Н. (1997), Понятие транспозиции, ее разновидности и функиии в современном русском языке (КЛЯ, разговорная речь и поэтический язык), [в:] Труды по русской и славянской филологии. Лингвистика, Тарту: ТГУ, Новая серия I, с. 154-171.

\section{Larysa Nakonechna}

\section{THE GRAMMEME TRANSPOSITION AS A LINGUISTIC PHENOMENON}

(Summary)

This article deals with the analysis of the grammeme transposition as a manifestation of the grammar transposition and the whole language one generally. The grammeme transposition is one of realisation method of the grammatical transposition and is realised between components of different grammatical categories. The terms of realisation and the ways of identification of the grammeme transposition have been analysed at the work.

The author referes to the scientific approach which is focused on a comprehensive study of the linguistic phenomena; the formal grammatical analysis; functional and communicative parameters as well as lexical-semantic parameters of grammatical categories and grammatical units. This approach to the analysis of linguistic facts is the conceptual framework for the researching of the grammeme transposition (as well as the language transposition generally).

Keywords: grammeme transposition, grammatical transposition, language transposition, grammatical category. 


\title{
Лариса Наконечная
}

\section{ГРАММЕМНАЯ ТРАНСПОЗИЦИЯ КАК ЯЗЫКОВОЕ ЯВЛЕНИЕ}

\author{
(Резюме)
}

Статья посвящена анализу граммемной транспозиции как одного из проявлений переходности в языке, разновидности грамматической транспозиции и языковой транспозиции в общем. Рассмотрен вопрос сути граммемной транспозиции, ее специфические черты и черты, объединяющие ее с иными видами грамматической транспозиции, проанализированы способы определения прямого и переносного, транспонированного, значения грамматической формы, контекстуальные средства транспозиции. Граммемная транспозиция в данной статье рассмотрена на примере грамматической категории времени глагола в украинском языке.

Ключевые слова: граммемная транспозиция, грамматическая транспозиция, грамматическая категория, грамиатическая форма. 